\title{
KEBERHASILAN PROGRAM DESA VOKASI TERHADAP PEMBERDAYAAN MASYARAKAT DI DESA GEMAWANG KABUPATEN SEMARANG
}

\section{THE SUCCESS OF THE VOCATIONAL PROGRAM FOR COMMUNITY EMPOWERMENT IN GEMAWANG VILLAGE, SEMARANG REGENCY}

\author{
Abdul Malik, Siti Irene Astuti Dwiningrum \\ Universitas Negeri Semarang, Universitas Negeri Yogyakarta \\ malofista@gmail.com, ireneast@yahoo.com
}

\begin{abstract}
Abstrak
Penelitian ini bertujuan mengungkapkan keberhasilan program desa vokasi terhadap pemberdayaan masyarakat berkaitan dengan: (1) pelaksanaan; (2) hasil (3) dampak; (4) faktor pendukung dan penghambat program. Penelitian ini menggunakan pendekatan deskriptif kualitatif. Subjek penelitian adalah tim pengembang desa vokasi, kepala desa, ketua dan peserta program. Pengumpulan data melalui: wawancara; observasi; dan dokumentasi. Teknik analisis data melalui: reduksi data; penyajian data; dan penarikan kesimpulan. Hasil penelitian mengungkapkan: (1) Pelaksanaan program desa vokasi melalui: seleksi wilayah, sosialisasi dan pembentukan pengurus, identifikasi dan pembentukan kelompok, pemilihan ketua kelompok, pelaksanaan diklat, dan pertemuan antar kelompok; (2) Hasil program berupa peningkatan kecakapan vokasi dan perkembangan kelompok usaha; (3) Dampak program berupa peningkatan ekonomi, status sosial dan perubahan budaya; (4) Faktor pendukung internal adalah tingginya target meningkatkan kualitas hidup, dan faktor pendukung eksternal ialah kuatnya komitmen aparat desa dan adanya pembinaan instansi terkait. Faktor penghambat internal adalah rendahnya motivasi. Faktor penghambat eksternal adalah cuaca, terbatasnya modal serta banyaknya pesaing dalam pemasaran.
\end{abstract}

Kata Kunci: program desa vokasi, pemberdayaan masyarakat.

\section{Abstract}

This study aims to reveal the perception the success of vocational to community empowerment about: (1) Implementation; (2) Results; (3) The impact; and (3) supporting and inhibiting factors the program.The study employed the qualitative descriptive approach. The research subjects comprised the team developing the vocational village, the village chief, the head of the program. The data were collected through: interviews, observations, documentation. The data were analyzed through the stages of data reduction, data display, and conclusion drawing or verification. The study reveals the following findings: (1) Implementation the Vocational Village Program through several steps including page region selection, socialization, identification and determination of the group, election of the chairman, the implementation of vocational education and training, vocational group; (2) Output rural vocational program consisting of an increase in vocational skills for each member of the group and the development of business groups; (3) Impact of the vocational village program is the increased economic, social status and cultural; (4) Internal supporting factor is the presence of the ideals of the program participants to achieve a better life, and external contributing factors is the strong commitment by village officials, and special group. While the internal limiting factor is the lack of motivation. External limiting factor is the state of the weather, the limited capital and many competitors in marketing.

Keywords: Vocational Village Program, Community Empowerment 


\section{PENDAHULUAN}

Kemiskinan merupakan masalah dalam pembangunan yang bersifat multidimensi. Kemiskinan ditandai oleh keterbelakangan dan pengangguran yang selanjutnya meningkat menjadi pemicu ketimpangan pendapatan dan kesenjangan antar golongan penduduk.

Data BPS menunjukkan bulan Maret tahun 2013, penduduk miskin di tingkat nasional mencapai 11,37 persen atau 28,07 juta jiwa. Di Jawa Tengah jumlah penduduk miskin mencapai 14,56 persen atau 4,733 juta jiwa. Tingginya angka kemiskinan tersebut disebabkan oleh tingginya angka pengangguran. Tingkat Pengangguran Terbuka (TPT) tahun 2012 6,32 persen dari total angkatan kerja yang berjumlah 120.400.00o. Sedangkan di Jawa Tengah TPT mencapai 1,02 juta orang atau 6,02 persen dari total angkatan kerja 16,99 juta orang. Di Kabupaten Semarang, TPT mencapai 3,88 persen.

Struktur tenaga kerja di Indonesia menurut tingkat pendidikan tergolong rendah. Hal ini dibuktikan dengan masih dominannya tenaga kerja lulusan SD ke bawah yang mencapai 49,21 persen atau 55,51 juta orang. Keadaan yang sama juga terjadi pada Provinsi Jawa Tengah, tenaga kerja berpendidikan SD ke bawah mencapai 53,71 persen atau 8,58 juta orang. Begitu pun di Kabupaten Semarang, tenaga kerja lulusan SD ke bawah mencapai 50,31 persen atau 258.390 orang.

Data tersebut menggambarkan bahwa struktur tenaga kerja dan kualitas SDM Indonesia masih rendah, sehingga menjadikan produktivitas dan rata-rata penghasilan pekerja Indonesia juga relatif rendah. Direktorat Pembinaan Kursus dan Kelembagaan, Departemen Pendidikan Nasional (2009, p.iv), menilai masalah tersebut terkait dengan masalah mutu dan relevansi pendidikan nasional. Sistem pendidikan dan pelatihan yang diterapkan di Indonesia lebih berorientasi pada penawaran program dari pemerintah pusat (supply driven) bukan dari kebutuhan masyarakat. Akibatnya terjadi kesenjangan atau gap dan ketidakcocokan (mismatch) antara penawaran (supply) dengan permintaan (demand), yang pada gilirannya berdampak terhadap rendahnya produktivitas dan tingginya pengangguran.

Sehubungan hal tersebut, salah satu Rencana Pembangunan Nasional Jangka Menengah (RPJM) 2010-2014 dirumuskan untuk mengatasi masalah kemiskinan di desa dari segi ketenagakerjaan, kualitas sumber daya manusia, dan kualitas pendidikan, pemerintah meningkatkan akses orang dewasa untuk mendapatkan pendidikan dan pelatihan kecakapan hidup, pengembangan dan pembinaan desa/kelurahan vokasi berbasis keunggulan lokal.

Direktorat Jenderal Pendidikan Anak Usia Dini Nonformal dan Informal (PAUDNI), menindaklanjuti RPJM (20102014) tersebut melalui Direktorat Pembinaan Kursus dan Kelembagaan, dengan penyelenggaraan berbagai program yang mengarah pada pembekalan kepada masyarakat sebagai pembelajar yang berbasis pada pendidikan kecakapan hidup, untuk memenuhi kebutuhan warga masyarakat baik pada spektrum pedesaan, perkotaan, nasional, dan internasional.

Pusat Pengembangan Pendidikan Nonformal dan Informal (P2PNFI) (sekarang $\mathrm{P}_{2} \mathrm{PAUDNI}$ ) Regional II yang mengembangkan model rintisan desa vokasi, yang diilhami dari program di Oita-Jepang dengan model The One Village, One Product $(O V O P)$ yang artinya satu desa satu produk. Inovasi pengembangan desa di Jepang ini juga diadopsi di Thailand sejak tahun 2001 yang dikenal dengan program desa OTOP (One Tambon One Product) artinya, setiap satu kecamatan harus memiliki minimal satu komoditas ekonomi unggulan. (Denpaiboon \& Amatasawatdee, 2012, p.53).

Sebelum menetapkan desa yang menjadi model desa vokasi, P2PAUDNI melakukan studi eksplorasi. Penentuan lokasi desa vokasi ini berdasarkan penilaian yang berorientasi pada: (a) jumlah keluarga miskin tinggi; (b) sasaran garapan pendidikan kecakapan hidup (PKH) tinggi; (c) sudah ada embrio unit-unit usaha yang memiliki banyak potensi untuk dikembangkan; (d) memiliki potensi sumber daya yang bisa dimobilsasi untuk mendukung desa vokasi; (e) akses memadai (informasi, pasar, modal, bahan baku); (f) diutamakan yang sudah 
memiliki embrio program PNF (TBM dan PKBM); (g) banyak sasaran program pada jalur pendidikan non formal.

Studi eksplorasi dilaksanakan terhadap 5 (lima) wilayah di Jawa Tengah, salah satunya Desa Gemawang. Jumlah keluarga miskin di Gemawang cukup tinggi, yakni sebesar 1.736 orang. Sasaran garapan vokasi berjumlah 871 orang. Embrio unit usaha yang telah dimiliki sebanyak 17 jenis. Potensi sumber daya yang dimiliki berupa perkebunan kopi, wisata, lebah madu, dan kelengkeng. Akses pasar tergolong cukup memadai untuk keberlangsungan usaha. Embrio program PNF yang dimiliki cukup variatif, ada Pusat Kegiatan Belajar Masyarakat (PKBM), Taman Bacaan Masyarakat (TBM), Kelompok Belajar Paket B (KPB), Pendidikan Anak Usia Dini (PAUD), Keaksaraan Fungsional (KF), dan Kursus Wirausaha Desa (KWD).

Pada mulanya P2PAUDNI mengujicobakan model desa vokasi di Gemawang terhadap 4 kelompok, diantaranya: Batik; Boga; Alat Permainan Edukatif (APE); dan Pertanian. Perkembangan selanjutnya, Dinas Pendidikan Provinsi Jawa Tengah dan Dinas Pendidikan Kabupaten Semarang mengembangkan beberapa kelompok, diantaranya Budidaya Kelinci; Madu Lebah; Garmen; Perikanan; Budidaya Jamur; Pupuk Bokashi; Kopi Bubuk; Pasta Indigo (pewarna batik alami).

Berdasarkan studi penduhuluan yang dilakukan terhadap 12 kelompok tersebut, ditemukan 3 (tiga) kelompok (batik, boga dan APE) yang masih aktif dan mampu dijadikan sebagai sumber penghasilan utama bahkan satu-satunya sumber penghasilan untuk memenuhi kebutuhan hidup diri dan keluarganya. Atas dasar inilah, maka penelitian ini hanya difokuskan pada tiga kelompok tersebut.
Berdasarkan kajian tersebut, penelitian ini bermaksud untuk mengetahui lebih dalam tentang keberhasilan program desa vokasi terhadap pemberdayaan masyarakat di Desa Gemawang kecamatan Jambu Kabupaten Semarang.

\section{METODE}

Penelitian ini menggunakan pendekatan kualitatif dengan metode deskriptif kualitatif. Penelitian dilaksanakan pada $\mathrm{Bu}-$ lan September 2012 sampai dengan Agustus 2013. Tempat penelitian di Desa Gemawang kecamatan Jambu kabupaten Semarang.

Subjek penelitian adalah anggota tim pengembang desa vokasi dari P2PAUDNI Regional II, kepala Desa Gemawang, ketua program desa vokasi, dan warga belajar/ peserta program.

Pengumpulan data dilakukan dengan: (1) riset kepustakaan, (2) teknik dokumentasi, (3) riset lapangan dengan cara (a) wawancara, (b) observasi, dan (c) dokumentasi. Keabsahan data diperiksa menggunakan teknik trianggulasi sumber dan metode. Trianggulasi sumber dilakukan dengan mengecek kembali hasil wawancara subjek satu dengan subjek lainnya. Trianggulasi metode dilakukan dengan cara memeriksa kembali hasil wawancara kemudian dibandingkan dengan dokumentasi atau observasi. Metode analisis data dilakukan dengan cara: (a) reduksi data, (b) penyajian data, dan (c) verifikasi atau penarikan kesimpulan.

\section{HASIL DAN PEMBAHASAN}

Berdasarkan hasil wawancara dengan subjek penelitian diperoleh data bahwa pelaksanaan program desa vokasi terdiri dari komponen input dan proses. Komponen input meliputi warga belajar, narasumber, pengelola/pengurus, pendanaan dan sarana dan prasarana. Komponen input disajikan pada tabel 1. 
Tabel 1. Komponen Input Program Desa Vokasi

\begin{tabular}{|c|c|c|c|}
\hline \multirow{2}{*}{ Komponen } & \multicolumn{3}{|c|}{ Kelompok Vokasi } \\
\hline & Batik & Boga & APE \\
\hline \multirow{3}{*}{$\begin{array}{l}\text { Warga } \\
\text { belajar }\end{array}$} & 20 orang $(\mathrm{L}=5, \mathrm{P}=15)$ & 10 rang & 10 orang \\
\hline & $\begin{array}{l}\text { Memiliki keterampilan } \\
\text { membatik dari Yayasan }\end{array}$ & $(\mathrm{L}=3, \mathrm{P}=7)$ & $(\mathrm{L}=10)$ \\
\hline & Losari & $\begin{array}{l}\text { Memiliki usaha kecil dan } \\
\text { menengah dalam bidang } \\
\text { boga }\end{array}$ & $\begin{array}{l}\text { Tidak memiliki keterampilan } \\
\text { dalam bidang APE }\end{array}$ \\
\hline Nara sumber & $\begin{array}{l}\text { Pengusaha Batik Trisik } \\
\text { Yogyakarta dan Solo }\end{array}$ & $\begin{array}{l}\text { Ikatan Alumni (IKA) Boga } \\
\text { Semarang }\end{array}$ & $\begin{array}{l}\text { Pengusaha APE dari Ujung- } \\
\text { ujung Pabelan }\end{array}$ \\
\hline Pengelola & \multicolumn{3}{|c|}{$\begin{array}{l}\text { Perwakilan: Aparat Desa } 4 \text { orang; tokoh pemuda } 3 \text { orang; dan tokoh masyarakat } 2 \text { orang } \\
\text { Pendidikan: Sariana } 4 \text { orang. Diploma } 1 \text { orang, dan } 4 \text { orang SMA/sederiat. }\end{array}$} \\
\hline Pendanaan & Rp.10 juta & Rp. 5 juta & Rp.1o juta \\
\hline $\begin{array}{l}\text { Sarana dan } \\
\text { prasarana }\end{array}$ & $\begin{array}{l}\text { Alat proses menggambar } \\
\text { dan membatik }\end{array}$ & $\begin{array}{l}\text { Alat-alat pembuatan } \\
\text { keripik singkong }\end{array}$ & $\begin{array}{l}\text { Alat-alat pengolahan dan } \\
\text { pewarna-an }\end{array}$ \\
\hline
\end{tabular}

Sumber: Diolah dari Data Primer, Tahun 2013

Tabel 2. Tahapan Program Desa Vokasi

\begin{tabular}{lll}
\hline Tahapan & \multicolumn{1}{c}{ Deskripsi } & \multicolumn{1}{c}{ Tujuan } \\
\hline Input & Kegiatan menelusuri karateristik komponen & $\begin{array}{l}\text { Agar lebih mudah berhasil mencapai } \\
\text { tujuan program }\end{array}$ \\
& yang mendukung pelaksanaan program & Menilai visibilitas desa untuk menjadi \\
& Rangkaian kegiatan melalui: & model rintisan desa vokasi \\
& 1) seleksi lokasi: kegiatan menyeleksi beberapa & Terwujudnya kesepahaman antara \\
desa calon sasaran melalui studi eksplorasi & pencetus program (P2PAUDNI) dengan \\
2) Sosialisasi: Proses penyampaian informasi & masyarakat desa sasaran, \\
dari pencetus program kepada masyarakat & Agar terjadi kerjasama yang kompak \\
sasaran melalui forum rembug desa & antar elemen masyarakat. \\
3) Pembentukan tim pengurus program & Terbentuknya kelompok vokasi yang \\
4) Identifikasi dan pembentukan kelompok & sesuai kebutuhan masyarakat. \\
vokasi & Terpeliharanya dinamika kelompok \\
5) Pemilihan ketua kelompok & Tercipta kemandirian masyarakat. \\
6) Pelaksanaan diklat & Tercipta hubungan yang harmonis antar \\
7) Pertemuan antar kelompok vokasi & kelompok vokasi \\
\hline
\end{tabular}

Sumber: Diolah dari Data Primer, Tahun 2013

Berdasarkan tabel 1 tersebut, dapat disimpulkan komponen input mendukung bagi lancarnya proses pelaksanaan program.

Proses pelaksanaan program desa vokasi melalui beberapa tahapan, antara lain: (1) seleksi lokasi (2) Sosialisasi; (3) Pembentukan pengurus; (4) identifikasi dan pembentukan kelompok belajar oleh pengurus program; (5) pemilihan ketua kelompok, sepenuhnya oleh anggota kelompok; (6) pelaksanaan diklat terdiri dari batik, boga dan APE; (7) pertemuan antar kelompok vokasi dilaksanakan setiap tiga bulan sekali. Deskripsi tentang tahapan program desa vokasi disajikan dalam tabel 2 berikut.

Hasil program desa vokasi berupa peningkatan kecakapan vokasi dan perkembangan kelompok usaha disajikan pada tabel 3 berikut. 
Tabel 3. Hasil Program Desa Vokasi

\begin{tabular}{|c|c|c|}
\hline \multirow[b]{2}{*}{$\begin{array}{c}\text { Kelompok } \\
\text { Vokasi }\end{array}$} & \multicolumn{2}{|r|}{ Hasil Program } \\
\hline & $\begin{array}{c}\text { Peningkatan kecakapan } \\
\text { vokasi }\end{array}$ & Perkembangan kelompok usaha \\
\hline Batik & $\begin{array}{l}\text { Terjadi peningkatan, } \\
\text { semula hanya menguasai } \\
\text { dasar membatik sekarang } \\
\text { ahli pewarnaan dan } \\
\text { pengecapan }\end{array}$ & $\begin{array}{l}\text { - } \text { Nama kelompok: Nyi Ageng Pandanaran } \\
\text { - } \text { Sekretariat: rumah AKF (ketua kelompok) } \\
\text { - } 20 \text { orang dilatih bertahan } 11 \text { orang } \\
\text { - } \\
\text { Penghasilan ketua kelompok lebih besar daripada saat } \\
\text { menjadi PNS } \\
\text { - }\end{array}$ \\
\hline Boga & $\begin{array}{l}\text { Terjadi peningkatan, } \\
\text { sebelumnya hanya } \\
\text { mampu membuat } \\
\text { makanan dari bahan } \\
\text { singkong sekarang } \\
\text { mampu membuat dari } \\
\text { bahan tempe. }\end{array}$ & 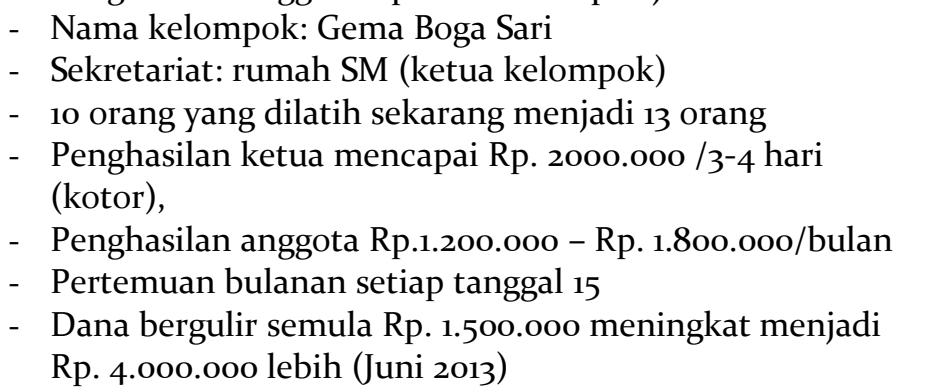 \\
\hline APE & $\begin{array}{l}\text { Terjadi peningkatan, } \\
\text { semula tidak mampu } \\
\text { membuat APE saat ini ahli } \\
\text { dalam bidang APE }\end{array}$ & $\begin{array}{l}\text { - Nama kelompok: Gema Indah Kreatif } \\
\text { - } \quad \text { Sekretariat: bengkel kerja MS (anggota kelompok) } \\
\text { - } 10 \text { orang dilatih, } 1 \text { orang bertahan } \\
\text { - } \\
\text { - }\end{array}$ \\
\hline
\end{tabular}

Sumber: Diolah dari Data Primer, Tahun 2013

Tabel tersebut menggambarkan bahwa hasil program desa vokasi berupa peningkatan kecakapan vokasi dan perkembangan kelompok usaha terjadi pada semua kelompok usaha.

Dampak program desa vokasi terhadap peserta program berupa peningkatan ekonomi, status sosial dan perubahan budaya. Secara ringkas, dampak program desa vokasi disajikan pada tabel 4 .

Tabel 4. Dampak Program Desa Vokasi

\begin{tabular}{|c|c|c|c|}
\hline \multirow{2}{*}{$\begin{array}{c}\text { Klp } \\
\text { Vokasi }\end{array}$} & \multicolumn{3}{|c|}{ Dampak } \\
\hline & Peningkatan Ekonomi & Peningkatan Status Sosial & Perubahan Budaya \\
\hline Batik & $\begin{array}{l}\text { Peningkatan pendapatan, } \\
\text { terutama ketua kelompok. } \\
\text { Satu hari bisa melebihi gaji } \\
\text { PNS satu bulan. } \\
\text { Akses terhadap pinjaman } \\
\text { modal pada Bank terbuka } \\
\text { lebar, angsuran belum selesai } \\
\text { sudah ditawari lagi. }\end{array}$ & $\begin{array}{l}\text { Peningkatan status sosial dengan } \\
\text { menjadi pengelola sekaligus } \\
\text { donatur lembaga PAUD, menjadi } \\
\text { pengurus dan membina kelompok } \\
\text { vokasi. }\end{array}$ & $\begin{array}{l}\text { Terjadi perubahan budaya } \\
\text { (pola pikir) berwujud mampu } \\
\text { membaca peluang dan } \\
\text { mempunyai visi yang lebih } \\
\text { baik. }\end{array}$ \\
\hline Boga & $\begin{array}{l}\text { Peningkatan pendapatan } \\
\text { hingga Rp. } 2 \text { juta per produksi } \\
\text { Terbukanya akses pinjaman } \\
\text { modal dari lembaga keuangan } \\
\text { (saat ini kredit mobil pick-up) }\end{array}$ & $\begin{array}{l}\text { Peningkatan status sosial dengan } \\
\text { lebih dipandang keberadaannya di } \\
\text { masyarakat: menjadi ketua karang } \\
\text { taruna desa Gemawang }\end{array}$ & $\begin{array}{l}\text { Terjadi perubahan gaya } \\
\text { hidup sistem nilai, yang } \\
\text { semula tidak percaya diri } \\
\text { menjadi lebih percaya diri. }\end{array}$ \\
\hline APE & $\begin{array}{l}\text { Peningkatan pendapatan dari } \\
\text { sebelumnya buruh bangunan } \\
\text { dan berkebun } \\
\text { Terbukanya akses pinjaman } \\
\text { modal dari Bank (hutang Rp. } \\
\text { 20 juta) }\end{array}$ & $\begin{array}{l}\text { Peningkatan status sosial dengan } \\
\text { menyumbang dana lebih besar } \\
\text { pada acara-acara sosial seperti } \\
\text { pengajian, pagelaran wayang dll. }\end{array}$ & $\begin{array}{l}\text { Terjadi perubahan budaya, } \\
\text { semula tidak berani } \\
\text { menanggung resiko menjadi } \\
\text { berani menanggung resiko. }\end{array}$ \\
\hline
\end{tabular}

Sumber: Diolah dari Data Primer, Tahun 2013 
Berdasarkan tabel 4 tersebut, dapat disimpulkan bahwa dampak program desa vokasi berupa peningkatan ekonomi, status sosial dan perubahan budaya terjadi pada semua kelompok.
Setiap kegiatan pasti memiliki pendukung dan penghambat. Faktor pendukung program desa vokasi terbagi atas internal dan eksternal. Secara sederhana disajikan pada tabel 5 berikut.

Tabel 5. Faktor Pendukung Program Desa Vokasi

\begin{tabular}{|c|c|c|}
\hline \multirow{2}{*}{$\begin{array}{c}\text { Klp } \\
\text { Vokasi }\end{array}$} & \multicolumn{2}{|r|}{ Faktor Pendukung } \\
\hline & Internal & Eksternal \\
\hline Batik & $\begin{array}{l}\text { Cita-cita/target menyekolahkan } \\
\text { anak hingga jenjang yang paling } \\
\text { tinggi }\end{array}$ & $\begin{aligned} & \text { - } \text { Komitmen yang kuat dari aparat desa } \\
& \text { - Pembinaan/pendampingan dari dinas terkait } \\
& \text { (P2PAUDNI, dinas pendidikan prov/kab dll) } \\
& \text { - Ditetapkannya batik sebagai pakaian nasional }\end{aligned}$ \\
\hline Boga & $\begin{array}{l}\text { Cita-cita/target suami berkumpul di } \\
\text { rumah (tidak merantau) }\end{array}$ & $\begin{aligned} & \text { - } \text { Komitmen yang kuat dari aparat desa } \\
& \text { - Pembinaan/pendampingan dari dinas terkait } \\
& \text { (P2PAUDNI, dinas pendidikan prov/kab dll) }\end{aligned}$ \\
\hline APE & $\begin{array}{l}\text { Cita-cita/target berkumpul lebih } \\
\text { lama bersama keluarga }\end{array}$ & $\begin{array}{l}\text { - Komitmen yang kuat dari aparat desa } \\
\text { - Pembinaan/pendampingan dari dinas terkait } \\
\text { (P2PAUDNI, dinas pendidikan prov/kab dll) }\end{array}$ \\
\hline
\end{tabular}

Sumber: Diolah dari Data Primer 2013

Dari tabel 5 tersebut dapat disimpulkan bahwa faktor pendukung keberhasilan program desa vokasi secara internal adalah kuatnya cita-cita/target meningkatkan kualitas hidup keluarga. Faktor pendukung eksternal terdiri atas komitmen yang kuat dari aparat desa, pembinaan dari dinas terkait untuk semua kelompok, khusus ke-lompok batik, kebijakan batik sebagai pakaian nasional menjadi faktor pendukung eksternal lain.

Faktor penghambat terdiri atas internal dan eksternal. Secara ringkas disajikan pada tabel 6 berikut.

Tabel 6. Faktor Penghambat Program Desa Vokasi

\begin{tabular}{|c|c|c|}
\hline \multirow{2}{*}{$\begin{array}{c}\text { Klp } \\
\text { Vokasi }\end{array}$} & \multicolumn{2}{|c|}{ Faktor Penghambat } \\
\hline & Internal & Eksternal \\
\hline Batik & $\begin{array}{l}\text { Rendahnya motivasi internal peserta } \\
\text { program ( } 20 \text { orang dilatih, } 11 \text { yang masih } \\
\text { aktif) }\end{array}$ & $\begin{array}{l}\text { - } \text { Kondisi cuaca (hujan) pada saat proses } \\
\text { produksi (pasca pewarnaan) } \\
\text { - } \text { Keterbatasan modal } \\
\text { - } \text { Banyaknya pesaing dalam hal pemasaran } \\
\text { (batik solo, yogya, pekalongan) }\end{array}$ \\
\hline Boga & $\begin{array}{l}\text { Tidak ada hambatan (1o orang dilatih, } \\
\text { seluruhnya masih aktif bahkan } \\
\text { bertambah menjadi } 13 \text { orang) }\end{array}$ & $\begin{array}{l}\text { - Kondisi cuaca (hujan) pada saat proses } \\
\text { produksi (pada kerupuk, udara lembab } \\
\text { menyebabkan keluarnya jamur) } \\
\text { - Terbatasnya modal mengakibatkan tidak } \\
\text { mampu menyiapkan cadangan produk pada } \\
\text { saat cuaca bersahabat }\end{array}$ \\
\hline APE & $\begin{array}{l}\text { Rendahnya motivasi internal peserta } \\
\text { program (10 orang dilatih, hanya } 1 \text { orang } \\
\text { yang masih bertahan) }\end{array}$ & $\begin{array}{l}\text { - Kondisi cuaca (hujan) pada saat proses } \\
\text { produksi (pengeringan) } \\
\text { - Banyak pesaing dalam hal pemasaran (produk } \\
\text { klaten lebih murah) }\end{array}$ \\
\hline
\end{tabular}

\section{Sumber: Diolah dari Data Primer 2013}

Dari tabel 6 tersebut dapat disimpulkan, bahwa faktor penghambat internal adalah rendahnya motivasi peserta untuk kelompok batik dan APE, namun tidak terjadi pada kelompok boga. Faktor peng-hambat eksternal antara lain cuaca (hujan) menyebabkan proses produksi terganggu, keterbatasan modal, dan banyaknya pesaing dalam pemasaran. 


\section{Pelaksanaan Program Desa Vokasi}

Pelaksanaan program desa vokasi di Desa Gemawang diawali oleh analisis input atau masukan.

Peserta program berasal dari berbagai latar belakang. Dari tiga kelompok yang diteliti hanya satu kelompok yang merupakan program rintisan yaitu APE, dua yang lainnya (batik dan boga) merupakan pengembangan. Oleh karena itu dari sisi karakteristik peserta program, anggota kelompok batik dan boga tidak termasuk kategori menganggur sebagaimana dalam pedoman. (P2PNFI Reg. II, 2009, p.18).

Karakteristik pendidik atau narasumber pada program desa vokasi, menunjukkan bahwa baik batik, boga maupun APE memiliki akses usaha dan berpengalaman sebagai instruktur. Narasumber pelatihan membatik didatangkan dari perusahaan batik Trisik Yogyakarta dan Solo, boga dari IKA Boga Semarang, dan APE dari Ujungujung Pabelan Salatiga. Ketiganya merupakan instruktur sekaligus pengusaha pada bidangnya masing-masing.

Karakteristik pengelola atau pengurus juga sudah sesuai dengan kriteria, yakni merupakan lulusan S1. Selain itu, Ketua Program juga pernah menjadi pemuda pelopor tingkat nasional pada tahun 2005. Hal ini menunjukkan kemampuannya dalam bidang manajemen dan kepemimpinan tidak diragukan lagi. Hal ini sejalan dengan kriteria P2PNFI (2009, p.19) yang mengharuskan jabatan ketua diberikan kepada orang yang dipilih masyarakat, berpendidikan S1, memiliki kemampuan manajemen dan kepemimpinan.

Komponen dana memegang peranan cukup penting demi keberlangsungan program. Besaran dana kelompok vokasi batik dan APE mendapatkan sebesar Rp. 10.000.00o, sedangkan kelompok boga mendapatkan dana Rp5.0oo.ooo.

Sarana prasarana program desa vokasi diberikan oleh P2PNFI Regional II. Anggaran sarana prasarana termasuk dalam dana yang telah dibahas tersebut. Dari ketiga kelompok yang diteliti, yang paling banyak menggunakan dana untuk pengadaan sarana dan prasarana adalah kelompok APE disebabkan karena program ini masih rintisan sehingga membutuhkan sarana dan prasana yang lebih banyak.

Proses pelaksanaan program desa vokasi dimulai dari penetapan lokasi yang akan dijadikan sebagai sasaran program desa vokasi melalui tahapan seleksi.

Seleksi lokasi menurut Mulyono (2012, p.851) merupakan langkah awal dalam tahapan strategi pemberdayaan masyarakat. Pada tahap ini, Mulyono menyebut sebagai tahapan memetakan sasaran program.

Tahapan seleksi wilayah (studi eksplorasi) yang dilakukan terhadap 5 (lima) wilayah di Jawa Tengah sebelumnya telah melewati serangkaian proses yang bersifat bottom-up, seperti menerima masukan/ usulan dari aparat desa dan melakukan diskusi dengan SKB-SKB di Jawa Tengah. Hal ini sejalan dengan sifat pemberdayaan yang lebih menggunakan pendekatan bottom-up daripada top-down. Soetomo (2011, p.106) menekankan bahwa peran pihak eksternal dalam proses pembangunan masyarakat lokal, sebaiknya atas permintaan masyarakat sendiri sesuai kebutuhan mereka. Pernyataan senada disampaikan Adams (2003, p.3), bahwa pemberdayaan yang sesungguhnya seharusnya berasal dari orang-orang yang ingin diberdayakan, bukan hanya berasal dari pihak yang ingin memberdayakan mereka. Begitu juga dengan desa Gemawang yang diwakili oleh Kepala Desa (BS) yang mengirim surat kepada Kepala P2PAUDNI (pihak eksternal) untuk menjadikan desa Gemawang sebagai pilot project Desa Vokasi.

Sosialisasi pada program desa vokasi menurut Wrihatnolo \& Dwidjowijoto (2007, p.3) sebagai tahapan penyadaran. Pada tahap ini masyarakat sasaran diberikan pencerahan agar terjadi penyadaran bahwa mereka juga berhak memiliki "sesuatu". Program desa vokasi menyadarkan masyarakat bahwa mereka memiliki sejumlah potensi yang dapat dikembangkan. Hal ini sejalan dengan pendapat Sulistiyani (2004, p.103), bahwa untuk mewujudkan derajat keberdayaan salah satu langkahnya adalah upaya penyadaran untuk memahami diri, potensi, kekuatan dan kelemahan, serta memahami lingkungannya. 
Selain itu, proses sosialisasi juga dapat menentukan minat atau ketertarikan masyarakat untuk berpartisipasi dalam program pemberdayaan masyarakat yang dikomunikasikan. Hal senada disampaikan WHO (1991) yang dikutip oleh Mayo (2006, p.156), bahwa partisipasi masyarakat dalam kaitannya dengan pemberdayaan masyarakat, 'memungkinkan orang untuk memutuskan dan mengambil tindakan yang mereka percaya sangat penting bagi perkembangan mereka'.

Pembentukan pengurus dilaksanakan melalui rembug desa yang kedua. Pemilihan ketua kelompok diserahkan sepenuhnya pada anggota kelompok masing-masing. Peran ketua kelompok sangat strategis dalam proses pemberdayaan masyarakat. Ketua kelompok dapat berperan sebagai stabilisator dalam kelompok. Suasana kelompok menurut Sudjarwo (2011, p.19) adalah salah satu unsur yang cukup menentukan apakah anggota merasa betah tinggal/tetap menjadi anggota atau tidak.

Pelaksanaan diklat dilaksanakan sesuai kebutuhan belajar peserta program. Kelompok batik membutuhkan materi tentang teknik pengecapan dan pewarnaan, kelompok boga membutuhkan penambahan cita rasa dan pengemasan, dan kelompok APE materi dasar pembuatan APE.

Pelaksanaan diklat pada program desa vokasi diikuti oleh sejumlah peserta. Batik diikuti oleh 20 orang peserta, boga 10 orang peserta, dan APE 10 orang peserta. Dalam setiap pelatihan membutuhkan instruktur (Nara Sumber Teknis) yang handal di bidangnya. Karena itu pengurus program dan tim pengembang desa vokasi $\mathrm{P}_{2}$ PAUDNI berusaha mendatangkan para ahli di bidangnya untuk memberikan materi diklat vokasi. Pertemuan antar kelompok vokasi dilaksanakan 3 bulan sekali. Khusus kelompok boga, pertemuan dilaksanakan setiap tanggal 15 .

\section{Hasil Program Desa Vokasi}

Hasil program desa vokasi adalah terjadinya peningkatan kecakapan vokasi dan perkembangan kelompok usaha baik bagi anggota kelompok batik, boga dan APE.
Selain peningkatan kecakapan vokasi, hasil program desa vokasi terlihat juga berupa perkembangan kelompok usaha. Hasil penelitian menunjukkan, dari perkembangan kelompok yang paling berhasil ada-lah boga. Kerja sama antar anggota jelas nampak sekali. Anggota saling membantu memasarkan produk satu sama lain. Kekompakan tim terjaga dengan baik. Menurut Sudjarwo (2011, p.16), kata kunci dinamika kelompok ialah pada kekompakkan/kesatuan kelompok (unity). Menurut Kindervatter (1979, p.64) karakteristik Pendidikan Non Formal (PNF) sebagai proses pemberdayaan adalah salah satunya fokus utama terletak pada warga belajar sebagai kelompok, bukan sebagai individu.

Berdasarkan banyaknya penghasilan, kelompok batik (khusus ketua) mendapatkan yang paling banyak karena bertindak sebagai pengusaha. Karena itu, hubungan ketua dan anggota kelompok batik seperti konsep patron-client. Istilah 'patron' berasal dari ungkapan bahasa Spanyol yang secara etimologis berarti 'seseorang yang memiliki kekuasaan (power), status, wewenang dan pengaruh'. Sedangkan klien berarti 'bawahan' atau orang yang diperintah dan yang disuruh. Selanjutnya, pola hubungan patron-client merupakan aliansi dari dua kelompok komunitas atau individu yang tidak sederajat, baik dari segi status, kekuasaan, maupun penghasilan, sehingga menempatkan client dalam kedudukan yang lebih rendah (inferior), dan patron dalam kedudukan yang lebih tinggi (superior). Atau, dapat pula diartikan bahwa patron adalah orang yang berada dalam posisi untuk membantu klien-kliennya. (Ridwansyah, 2010, p.1)

Keterampilan membuat APE merupakan keterampilan baru bagi masyarakat Gemawang atau disebut rintisan. Maka tidak heran jika secara kuantitas (jumlah peserta) yang bertahan menekuni usaha ini 1 orang dari 10 orang yang diberi diklat. Namun dari sisi kualitas, anggota yang masih bertahan tergolong berhasil. Hal ini ditunjukkan dengan kesuksesannya memperluas (diversifikasi) usaha, menjadi produsen meubel bersama 2 (dua) orang pekerjanya. 


\section{Dampak Program Desa Vokasi}

Kindervatter (1979, p.13) juga mengemukakan empowering is:

people gaining an understanding of and control over social, economic, and/or political forces in order to improve their standing in society

Artinya, pemberdayaan diartikan sebagai seseorang memperoleh pemahaman dan pengendalian kekuatan sosial, ekonomi, dan/ atau politik untuk memperbaiki keberadaannya dalam masyarakat.

Dampak program desa vokasi diantaranya adalah peningkatan ekonomi, status sosial masyarakat dan perubahan budaya. Peningkatan ekonomi bisa dilihat dari peningkatan pendapatan peserta program. Peserta program yang dahulu belum mampu mencukupi kebutuhan hidup diri dan keluarganya, karena usaha (kerja) sebagai kuli bangunan dan "ngalas", saat ini sudah mengalami peningkatan pendapatan tanpa harus "ngalas". Ada juga peserta program yang dahulu sebagai PNS, kini menjadi perajin batik dan pendapatannya terkadang bisa 1 hari sama dengan atau bahkan lebih banyak daripada gajinya saat menjadi PNS. Selain itu ada juga peserta yang sebelumnya tidak mampu mencukupi kebutuhan seharihari sekarang sudah mampu, bahkan alat transportasi untuk pemasaran produk sudah menggunakan mobil pick-up.

Selain peningkatan pendapatan, dampak lainnya adalah terbukanya akses terhadap pinjaman modal dari lembaga keuangan baik Bank ataupun Non-Bank. Hasil penelitian menunjukkan, beberapa peserta program telah diberi kepercayaan oleh pihak Bank untuk meminjam dana puluhan juta hingga ratusan juta rupiah. Temuan tersebut sejalan dengan pendapat Sulistiyani (2004, p.103), terbukanya akses terhadap lembaga keuangan adalah termasuk tingkat keberdayaan yang kedua setelah tingkat keberdayaan terpenuhinya kebutuhan dasar.

Dampak lainnya adalah peningkatan status sosial masyarakat. Peserta program desa vokasi yang hingga saat ini menekuni usahanya, kini lebih dipandang oleh masya- rakat. Hal ini dapat ditunjukkan dengan semakin berpartisipasinya peserta program dalam pembangunan masyarakat. Status sosial menurut Soekanto (2012, p.210) artinya adalah tempat seseorang secara umum dalam masyarakatnya sehubungan dengan orang-orang lain, dalam arti lingkungan pergaulannya, prestisenya, dan hak-hak serta kewajiban-kewajibannya. Dengan demikian dapat disimpulkan bahwa dampak pemberdayaan pada program desa vokasi terhadap peningkatan sosial telah terwujud.

Perubahan budaya masyarakat juga menjadi salah satu dampak program. Perubahan budaya yang diharapkan terjadi sebagai dampak program desa vokasi seperti yang tercantum dalam tujuan umum program desa vokasi, yaitu terciptanya sikap mental kewirausahaan. Sikap mental wirausaha diantaranya adalah adalah mempunyai visi atau pandangan jauh ke depan sebagai sasaran yang akan dituju dalam perjuangannya meraih kesuksesan dan mampu melihat peluang. (Astamoen, 2008, pp.53-54). Sikap mental tersebut telah dimiliki oleh peserta program desa vokasi yang masih aktif menekuni usaha yang dilatihkan.

\section{Faktor Pendukung dan Penghambat}

Faktor pendukung dalam program dibagi menjadi dua, yaitu: pendukung internal dan pendukung eksternal. Adapun yang menjadi faktor pendukung internal adalah cita-cita atau target dari peserta program desa vokasi untuk memperbaiki kualitas hidupnya. Target tersebut kemudian menjadi pendorong timbulnya semangat dari dalam individu tersebut untuk berusaha merubah (tidak nrimo) terhadap keadaan yang belum berdaya menuju keadaan yang lebih berdaya. Hal ini meru-pakan salah satu ciri dari individu modern yang disampaikan Kahl dan dikutip oleh Lauer (1993, p.147), manusia modern adalah orang yang aktif; ia berupaya membentuk kehidupannya dan memberikan tanggapan terhadap takdirnya (tidak nrimo). Sejalan dengan Kahl, Mc Clelland (1961) yang dikutip dari Hendytio dan Babari (1996, p.177) juga menyatakan pentingnya dorongan dari dalam diri 
seseorang (Nach/need for achievement) bagi perbaikan keadaan diri dan lingkungannya.

Faktor pendukung eksternal adalah komitmen yang kuat dari aparat desa, pembinaan dari P2PAUDNI Regional II, dan berbagai dinas terkait seperti Dinas Pendidikan dan Kebudayaan, Dinas Perindustrian, dan Dinas Koperasi dan UMKM. Selain faktor tersebut, khusus untuk kelompok vokasi batik terdapat faktor yang lain, yaitu ditetapkannya batik sebagai warisan kemanusiaan untuk budaya lisan dan non-bendawi oleh UNESCO tahun 2009. Kemudian disambut dengan kebijakan nasional yang menetapkan setiap tanggal 2 Oktober sebagai Hari Batik Nasional. Dampaknya, instansi-instansi pemerintah mewajibkan berseragam batik pada hari tertentu yang pada gilirannya meningkatkan permintaan terhadap pakaian batik.

Faktor penghambat internal adalah kurangnya motivasi dari dalam diri peserta yang mengakibatkan ketidakkonsistenan peserta dalam menekuni usaha ini. Hal ini terlihat dari semakin berkurangnya anggota kelompok vokasi, seperti anggota kelompok vokasi batik dari yang semula 20 orang, hanya tersisa 11 orang dan anggota kelompok vokasi APE dari 10 orang, hanya tersisa 1 orang. Kurangnya motivasi peserta sebagai faktor penghambat pemberdayaan pada program desa vokasi oleh Hikmat disebutkan sebagai "mudah pasrah/menyerah/putus asa" (Hadiyanti, 2006, p.20). Sedangkan menurut Nasdian (2014, p.102) sebagai kendala pemberdayaan dari dimensi kultural, yaitu sikap pasrah akibat terjerat berbagai macam kekurangan sehingga tidak memiliki inisiatif, gairah, dan tidak dinamis mengubah nasib yang kurang baik.

Penghambat eksternal, yaitu diantaranya cuaca pada saat proses produksi. Proses produksi membatik memerlukan cuaca yang bersahabat, misalnya pada proses pengeringan kain setelah proses pewarnaan. Begitu pun proses produksi APE. Setelah proses pengecatan tentu diperlukan pengeringan. Jika cuaca hujan maka berdampak pada lamanya proses pengeringan. Begitu juga dengan boga, kerupuk rambak misalnya jika cuaca hujan kerupuk akan sulit kering hingga menimbulkan munculnya jamur.
Faktor penghambat lainnya adalah modal. Karena keterbatasan modal produksi sedikit terhambat. Hal ini sejalan dengan penelitian Isife, et.al (2009, p.24) yang menemukan bahwa program-program dari pusat kerajinan tangan dan industri pedesaan sebagian besar masyarakat miskin terhambat oleh sumber daya keuangan. Faktor lainnya adalah faktor banyaknya pesaing dalam proses pemasaran.

\section{PENUTUP}

\section{Simpulan}

Berdasarkan deskripsi hasil penelitian dan pembahasan mengenai keberhasilan program desa vokasi terhadap pemberdayaan masyarakat di Desa Gemawang Kecamatan Jambu Kabupaten Semarang, maka peneliti mengambil beberapa kesimpulan sebagai berikut:

Pelaksanaan program desa vokasi terdiri dari komponen input dan proses. Pertama input, terdiri dari: warga belajar/ peserta program yang memiliki karakteristik kemampuan awal pada kelompok batik dan boga, sedangkan APE tidak memiliki kemampuan dasar; narasumber merupakan ahli di bidang masing-masing; pengelola/ pengurus program terdiri dari perwakilan tokoh masyarakat, aparat desa dan tokoh pemuda; pendanaan berasal dari P2PNFI Regional II; dan sarana dan prasarana yang dimiliki berupa alat dan bahan untuk mendukung proses produksi batik, boga dan APE.

Kedua, proses terdiri dari beberapa tahapan diantaranya: seleksi lokasi; sosialisasi dan pembentukan tim pengelola/pengurus; identifikasi dan pembentukan kelompok vokasi; pemilihan ketua kelompok; pelaksanaan pelatihan (diklat) vokasi; dan pertemuan antar kelompok.

Program desa vokasi menghasilkan keluaran warga belajar yang mengalami peningkatan kecakapan vokasi dan perkembangan kelompok usaha. Kelompok batik dari 20 orang yang didiklat, 11 orang masih aktif. Penghasilan jauh meningkat terutama bagi ketua kelompok. Kelompok boga dari 10 orang yang didiklat bertambah menjadi 13 orang yang aktif melakukan usaha. Pengha- 
silan meningkat bagi semua anggota kelompok.

Perkembangan kelompok APE secara kuantitas negatif, dari 10 orang yang mengikuti diklat hanya 1 orang yang masih bertahan. Namun dari sisi kualitas cukup berhasil ditunjukkan dengan mampu melakukan diversifikasi usaha dengan menjadi produsen meubeler dan memiliki 2 orang karyawan. Dari sisi penghasilan cukup untuk memenuhi kebutuhan keluarganya.

Program desa vokasi diharapkan memiliki dampak terhadap peningkatan ekonomi, status sosial dan perubahan budaya. Peningkatan ekonomi dimaknai sebagai peningkatan pendapatan dan terbukanya akses terhadap lembaga keuangan. Peningkatan pendapatan dirasakan oleh anggota kelompok vokasi baik batik, boga maupun APE. Akses terhadap pinjaman modal dari lembaga keuangan juga dirasakan sangat terbuka.

Dampak yang lain adalah terhadap peningkatan status sosial. Anggota kelompok vokasi saat ini lebih dipandang keberadaannya di masyarakat dengan banyak dilibatkan dalam kegiatan-kegiatan sosial.

Perubahan budaya, juga menjadi dampak program. Perubahan ke arah sikap mental wirausaha telah nampak pada peserta, seperti memiliki visi, mampu membaca peluang, dan percaya diri.

Faktor Pendukung dan Penghambat Program

Faktor pendukung internal adalah cita-cita/target yang kuat dari dalam individu peserta untuk meningkatkan kualitas hidup keluarganya. Faktor pendukung eksternal adalah komitmen yang kuat dari aparat desa, pembinaan dari instansi terkait dan khusus untuk kelompok batik ditambah ditetapkannya batik sebagai pakaian nasional.

Faktor penghambat internal adalah rendahnya motivasi dari dalam individu. Sedangkan faktor penghambat eksternal terdiri dari kondisi cuaca (hujan) yang menghambat proses produksi. Selain itu, keterbatasan modal dan banyaknya pesaing pada pemasaran juga menjadi penghambat eksternal.

\section{Saran}

Kepada Pemerintah, program-program yang bertujuan memberdayakan masyarakat agar selalu memperhatikan proses seperti seleksi lokasi, sosialisasi, dan seterusnya. Seleksi lokasi hendaknya mempertimbangkan potensi yang dimiliki wilayah sasaran, baik potensi SDA maupun SDM. Sosialisasi sebaiknya melibatkan seluruh lapisan masyarakat, agar tujuan program dapat tercapai dengan baik. Proses pemberdayaan hendaknya diserahkan sepenuhnya kepada masyarakat sasaran agar mereka merasa memiliki program tersebut.

Kepada P2PAUDNI Regional II, perlu ditinjau ulang model desa vokasi yang telah diluncurkan dengan memperhatikan setiap tahapan seperti yang telah diteliti. Selain itu, pelaksanaan diklat/kursus keterampilan (kecakapan vokasi) yang belum memiliki embrio di wilayah sasaran, hendaknya dilakukan lebih lama dan mendalam agar keterampilan tersebut dapat benar-benar dikuasai dan kemudian menjadi sandaran hidup peserta program.

Kepada pengurus program, perlu membangun hubungan yang sinergis dengan berbagai stakeholder antara lain: pemerintah; dunia usaha dan dunia industry (DUDI); lembaga keuangan, dan masyarakat sasaran, agar keberlanjutan program dapat terjaga dengan baik.

\section{DAFTAR PUSTAKA}

Adams, R. (2003). Social work and empowerment ( $3^{\text {rd }}$ ed). New York: Palgrave McMilland

Astamoen, M.P. (2008). Entrepreneurship dalam perspektif kondisi bangsa indonesia. Bandung: Alfabeta.

BPS, (2013). Berita resmi statistik, BPS Provinsi Jawa Tengah, No.69/11/33/ Th.VII, o6 November 2013.

Denpaiboon, C. \&Amatasawatdee, C. (2012). Similarity and difference of one village one product (OVOP) for rural development strategy in japan and thailand. Japanese Studies Journal Special Issue: Regional Cooperation 
for Sustainable Future in Asia, pp.5262.

Depdiknas. (2009). Pengembangan model pendidikan kecakapan hidup SD/MI/ SDLB/SMP/MTS/SMPLB-SMA/MA/ $S M A L B / S M K / M A K$. Pusat Kurikulum Badan Penelitian dan Pengembangan Depdiknas. www.puskur.net

Hadiyanti, P. (2006). Kemiskinan dan upaya pemberdayaan masyarakat. Komunitas, Jurnal Pengembangan Masyarakat Islam Volume 2, Nomor 1, Juni 2006. pp.33-46.

Hendytio, M.K., \& Babari, J. (1996). Pemberdayaan kelompok pekerja. Dalam Prijono, O.S., \& Pranarka, A.M.W. (Eds). (1996). Pemberdayaan: konsep, kebijakan dan implementasi.(hal.173-192). Jakarta: Centre for Strategic and International Studies

Isife, B.I., Nnodim, U.A., \& Ochomma, U.C. (2009). Constraints to government's capacity building programmes in rural communities of rivers state, Southern Nigeria. Current Research Journal of Social Sciences 1(2): pp.2326. 2009 ISSN: 2041-3246

Kindervatter, S. (1979). Nonformal education as an empowering process. Amherst: Center for International Education.

Lauer, R.H. (1993). Perspektif tentang perubahan sosial. (Terjemahan Alimandan S.U.). Jakarta: PT. Rineka Cipta.

Mayo, M. (2006). Cultures, communities, identities cultural strategies for participation and empowerment. New York: Palgrave McMilland
Mulyono, S.E., \& Susilowati, I. 2012. The strategy of urban alleviation through empowering the young unemployed people in municipality of Semarang, Central Java-Indonesia: Introducing A-B-G-C Collaboration. China-USA Business Review. 11(108): pp.844-853. 2012 ISSN: 1537-1514.

Nasdian, F.T. (2014) Pengembangan masyarakat. Jakarta: Yayasan Obor Indonesia.

P2PNFI. (2009). Model desa vokasi berbasis keunggulan komparatif lokal. Bidang Kajian Kursus dan Kelembagaan. P2PNFI Regional 2 Semarang.

Ridwansyah, Y.A. (2010). Negeri patron-klien bernama Indonesia. Diambil pada tanggal 2 Januari 2014, dari http://ridwansyahyusufachmad.com /2010/05/30/negeri-patron-klienbernama-indonesia/

Soekanto, S. (2012). Sosiologi suatu pengantar. Jakarta: Rajawali Pers.

Soetomo. (2011). Pemberdayaan masyarakat mungkinkah muncul antitesisnya? Yogyakarta: Pustaka Pelajar.

Sudjarwo. (2011). Dinamika kelompok. Bandung: CV. Mandar Maju.

Sulistiyani, A.T. (2004). Kemitraan dan model-model pemberdayaan. Yogyakarta: Penerbit Gava Media

Wrihatnolo, R.R. \& Dwidjowijoto, R.N. (2007). Manajemen pemberdayaan sebuah pengantar dan panduan untuk pemberdayaan masyarakat. Jakarta: PT. Elex Media Komputindo. 